\title{
Impact of pumpkin as a nutritional supplement on the physico-chemical and organoleptic characteristics of a puncake
}

\author{
Iryna Lupekha, Olena Podobii
}

National University of Food Technologies, Kyiv, Ukraine

Keywords:

Cupcake

Pumpkin

Organoleptic

Additive

Rheology

Article history:

Received 29.08.2017

Received in revised

form 26.11.2017

Accepted 29.12.2017

Corresponding author:

Iryna Lupekha

E-mail:

lupekhairina@

gmail.com

\section{Abstract}

Introduction. Studies have been conducted to determine the influence of nutritional additives on the basis of pumpkin on the energy value, physico-chemical and organolleptic properties of confectionery flour products.

Materials and methods. The samples of cupcake with the addition of raw and blanched pumpkins in quantities of $8,16,24$ and $32 \%$ were studied. Rheological parameters have been investigated using rotational viscometry.

Results and discussion. The most successful formulation is to replace the classical components of the muffin with a functional additive of $24 \%$ blanched pumpkin. The use of various forms of pumpkin as a food additive in the manufacture of cakes is appropriate in view of the enrichment of the product with biologically valuable components, vitamin and mineral complexes and compounds of antioxidants contained in this raw material.

Having analyzed the physical and chemical parameters of the samples, the following results can be made: on the curves of viscosity with an increase in $\mathrm{P}, \mathrm{Pa}$ from 0 to 6000 $\eta$ increases from 0 to 450 for a parabolic dependence, with the most intense growth - in the range of $P$ in 5000. Increase of the additive from $8 \%$ to $32 \%$ increases $\eta$ on average $2-3$ times. Similarly, with an increase in $\mathrm{P}$, the flow curves $\varepsilon$ increases from 0 to 800 with the highest peak at 640 and then decreases.

According to the analyzed organoleptic indicators, the most successful are formulations with the addition of $16 \%$ and $24 \%$ blanched pumpkin.

Creating a new type of cupcake will help expand the range of specialty pastry flour confectionery.

Conclusions. It is rational to replace traditional components of cupcake with pumpkin with the quality assurance of products by physical and organoleptic characteristics.

DOI: $10.24263 / 2310-$

1008-2017-5-2-3 


\section{Introduction}

Flour confectionery products occupy an important place in the diet of the population and are in great demand. The essential disadvantage of this product group is the low content of essential substances (vitamins, minerals, food fibers, etc.) and high content of carbohydrates and fats. Therefore, a significant demand for these products necessitates the adjustment of their chemical composition. Taking into account the requirements of the science of nutrition, using non-traditional ingredients, the recipe of this group of products may be able to model and create nutritionally enriched foods with biologically active substances. One of the ways to create such products is to use additives with significant content of essential substances. As such raw can be used pumpkin[1].

The development and introduction of the newest technologies of flour confectionery with the use of functional ingredients is relevant in our time, contributes to the improvement of nutritional value, organoleptic parameters, and reduction of caloric content[2].

An overview of literary sources on assortment, technologies for the production of cakes showed that today there are no industrial technologies and formulations of carotinoid additives, such as pumpkin and cupcakes, with their use for health nutrition, both in restaurants, as well as in bakery. The assortment of cakes enriched with natural carotenoid herbal supplements abroad is also limited. An effective way to improve the vitamin content of the population is the additional enrichment of vitamins in food products of mass consumption.

The aim of research is to determine the impact of pumpkin as a nutritional supplement on the physico-chemical and organoleptic characteristics of a puncake.

\section{Analysis of recent researchs and publications}

Pumpkin (Cucurbita) - generic name of annual and perennial plants of the pumpkin family. Varieties of pumpkins differ in shape, size and color of the fruits. Some varieties of pumpkin breed for the sake of delicious and useful edible fruits, others - as decorative plants, and from the third, they make utensils and musical instruments $[3,5]$.

Pumpkin - a natural vitamin and mineral complex. The champion among the vitamins contained in the pumpkin is beta-carotene. For comparison: in orange varieties of betacarotene several times more than in carrots. In addition, the pumpkin is rich in vitamins $\mathrm{C}$, B1, B2, PP, that is, it contains a lot of potassium, calcium, iron, magnesium, copper, zinc, cobalt, silicon, fluorine.

1. Calorific value $21.4 \mathrm{kcal}$

2. Carbohydrates $4.4 \mathrm{~g}$

3. Fat 0.1 gr

4. Proteins $1.0 \mathrm{~g}$

5. Water $91.8 \mathrm{gr}$

6. Mono and disaccharides $4.2 \mathrm{~g}$

7. Starch $0.2 \mathrm{~g}$

8. Nutrient Fibers $2.0 \mathrm{~g}$

9. Organic acids $0.1 \mathrm{~g}$

10. Ash $0.6 \mathrm{~g}$
11. Vitamins:

Vitamin A $1.5 \mathrm{mg}$

Vitamin B1 $0.05 \mathrm{mg}$

Vitamin B2 is $0.06 \mathrm{mg}$

Vitamin B3 $0.4 \mathrm{mg}$

Vitamin B6 $0.1 \mathrm{mg}$

Vitamin B9 $14.0 \mu \mathrm{g}$

Vitamin C $8.0 \mathrm{mg}$

Vitamin PP $0.5 \mathrm{mg}$

Blanching is a culinary method that involves the rapid boiling of products in boiling water. Sometimes this term means scalding with boiling water. In the process of blanching, 
some of the products begin to bilelit - hence the characteristic name of this culinary admission. By the way, the very word "blanching" comes from the French blanchir, that is, "whitewash"[4].

Blanching is carried out as follows: in boiling water, the products are placed and they expect to re-boil water. From this moment it is accepted to deduct the time required for blanching - as a rule, about 2-3 minutes. If the products remain in boiling water longer, in this case it is a different culinary process - cooking.

Blanching is used to disinfect the products and, in addition, it also replaces cooking for some vegetables that are tender. Thus, the prolonged processing of vegetables, for example, hot water contributes to the loss of most of the vitamins, and blanching, in turn, relates to the fruits of the sparing, softening them. In addition, using a blanching on vegetables, a protective film is created, which helps to keep the products juicy and give them a more vivid taste [6].

\section{Material and methods}

\section{Materials}

Pumpkin and cupcakes were researched. Physical and chemical properties, organoleptic characteristics of made cupcakes with the addition of functional additives and without were analyzed.

Four formulations of cupcakes were developed with the addition of various forms of pumpkin.

Classic cupcake recipe

Table 1

\begin{tabular}{|c|c|c|}
\hline Component & Quantity, g & Quantity, \% \\
\hline Butter & 200 & 26,4 \\
\hline Egg & $120(3 \mathrm{pcs})$ & 15,8 \\
\hline Flour & 200 & 26,4 \\
\hline Sugar & 200 & 26,4 \\
\hline Vanilla & 15 & 2 \\
\hline Ripper & 15 & 2 \\
\hline Salt & 7,5 & 1 \\
\hline Total & 757,5 & 100 \\
\hline
\end{tabular}

Developed cupcake recipe with addition of $8 \%$ of pumpkin

Table 2

\begin{tabular}{|c|c|c|}
\hline Component & Quantity, g & Quantity, \% \\
\hline Butter & 180 & 23,8 \\
\hline Egg & $120(3 \mathrm{pcs})$ & 15,8 \\
\hline Flour & 180 & 23,8 \\
\hline Sugar & 180 & 23,8 \\
\hline Vanilla & 14,7 & 1,9 \\
\hline Ripper & 14,7 & 1,9 \\
\hline Salt & 7,5 & 1 \\
\hline Pumpkin & 60,6 & 8 \\
\hline Total & 757,5 & 100 \\
\hline
\end{tabular}


Developed cupcake recipe with addition of $16 \%$ of pumpkin

\begin{tabular}{|c|c|c|}
\hline Component & Quantity, g & Quantity, \% \\
\hline Butter & 160 & 21,1 \\
\hline Egg & $120(3 \mathrm{pcs})$ & 15,8 \\
\hline Flour & 160 & 21,1 \\
\hline Sugar & 160 & 21,1 \\
\hline Vanilla & 14,6 & 2 \\
\hline Ripper & 14,6 & 2 \\
\hline Salt & 7,1 & 0,9 \\
\hline Pumpkin & 121,2 & 16 \\
\hline Total & 757,5 & 100 \\
\hline
\end{tabular}

Developed cupcake recipe with addition of $24 \%$ of pumpkin

Table 4

\begin{tabular}{|c|c|c|}
\hline Component & Quantity, g & Quantity, \% \\
\hline Butter & 140 & 18,5 \\
\hline Egg & $120(3 \mathrm{pcs})$ & 15,8 \\
\hline Flour & 140 & 18,5 \\
\hline Sugar & 140 & 18,5 \\
\hline Vanilla & 14,4 & 1,9 \\
\hline Ripper & 14,4 & 1,9 \\
\hline Salt & 6,9 & 0,9 \\
\hline Pumpkin & 181,8 & 24 \\
\hline Total & 757,5 & 100 \\
\hline
\end{tabular}

Table 5

Developed cupcake recipe with addition of $32 \%$ of pumpkin

\begin{tabular}{|c|c|c|}
\hline Component & Quantity, g & Quantity, \% \\
\hline Butter & 130 & 17,2 \\
\hline Egg & $80(2 \mathrm{pcs})$ & 10,6 \\
\hline Flour & 140 & 18,5 \\
\hline Sugar & 130 & 17,2 \\
\hline Vanilla & 14,2 & 1,8 \\
\hline Ripper & 14,2 & 1,8 \\
\hline Salt & 6,7 & 0,9 \\
\hline Pumpkin & 242,4 & 32 \\
\hline Total & 757,5 & 100 \\
\hline
\end{tabular}

\section{Methods}

The study of structural and mechanical properties of the samples were performed on viscometer (Figure 1). 
Each of the samples under study, in the amount of $30-40 \mathrm{~cm}^{3}$, is introduced into the stationary outer cylinder of the device (1). After the test samples are applied, the inner cylinder S2 (2) is worn on the axle (3), which is connected to the electric motor. The outer cylinder (1) with the sample is worn on the fixed inner cylinder S2 (2) and lifted to the stop. The position of the outer cylinder is fixed with the help of a nut. The investigated sample is evenly distributed in the gap (4) between the coaxial cylinders - external 1 and internal 2 . Next, the potentiometer readings for each test sample are removed at various twelve strain rates.

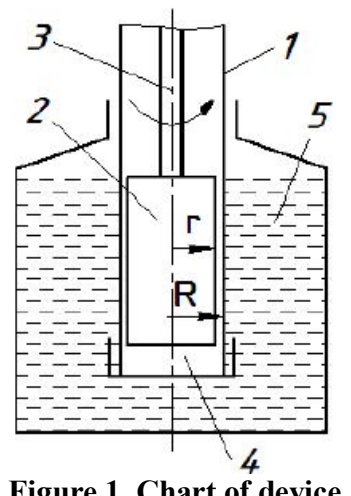

Figure 1. Chart of device

The stresses of the displacement $\mathrm{P}$, which arises in the system, is calculated by the equation:

$$
P=Z \cdot \alpha
$$

where $\mathrm{Z}$ - has become an internal cylinder; a - value of the scale on the indicator device (potentiometer);

The values of deformation gradients for each speed (12 values) were taken from the passport data.

By the values of the shear stress $\mathrm{P}$ and the deformation gradient, calculate the dynamic viscosity $\eta$ by the Newton equation:

$$
\eta=P / \dot{\varepsilon}
$$

where $\eta$ is the dynamic viscosity, $\mathrm{Pa} \times \mathrm{s} ; \mathrm{P}-$ shear stress, $\mathrm{Pa} ; \dot{\varepsilon}-$ shear rate, $\mathrm{s}^{-1}$.

According to the calculated data, construct complete rheological curves of viscosity and fluidity.

An organoleptic assessment of the quality of toothpastes is carried out using the descriptor-profile method [12].

Were offered a list of organoleptic indicators:

1. Shape

2. Surface

3. Color

4. View in fault 
A 5-point scale was created and profiles of quality indicators were performed on scale. This made it possible to systematically approach the quality assessment and clearly assess the quality of indicators and determine the level of quality. Also, identify indicators with significant deviations.

Organoleptic evaluation of cakes should be given in accordance with the Table 6 .

Organoleptic evaluation of cupcakes

Table 6

\begin{tabular}{|c|l|l|}
\hline Indicator & \multicolumn{2}{|c|}{ Characteristic } \\
\cline { 2 - 3 } & \multicolumn{1}{|c|}{ Cupcakes without stuffing } & \multicolumn{1}{c|}{ Cupcakes with filling } \\
\hline Shape & $\begin{array}{l}\text { Correct, that corresponds to the } \\
\text { form, established according to the } \\
\text { formulation, without breakages }\end{array}$ & $\begin{array}{l}\text { Round, rectangular, not deformed, } \\
\text { without inflow, is inherent in the form in } \\
\text { which products are baked, without } \\
\text { contamination }\end{array}$ \\
\hline Surface & $\begin{array}{l}\text { Not burned. The glazing of } \\
\text { cupcakes should not have marks } \\
\text { of "graying" and stains. } \\
\text { The surface of cupcakes made on } \\
\text { chemical rashes may be due to the } \\
\text { presence of cracks and gaps that } \\
\text { do not alter the product's } \\
\text { appearance. } \\
\text { Glaze should not be sticky. }\end{array}$ & $\begin{array}{l}\text { With the presence of insignificant cracks } \\
\text { and gaps that do not change the product's } \\
\text { appearance without burning. } \\
\text { It is permissible to adhere to the } \\
\text { packaging material on the side and side } \\
\text { of the product, the sinking hole, as well } \\
\text { as a small amount of filling on the } \\
\text { surface of the cupcake. }\end{array}$ \\
\hline Color & $\begin{array}{l}\text { From light brown to dark brown. } \\
\text { The color of the lower crust may } \\
\text { differ from the color of the upper } \\
\text { side. }\end{array}$ & $\begin{array}{l}\text { From light yellow to brown, the bottom } \\
\text { and the side surface are lighter. }\end{array}$ \\
\hline View in \\
fault & $\begin{array}{l}\text { A well baked cupcake, no } \\
\text { hardening and no traces. }\end{array}$ & $\begin{array}{l}\text { Well cooked, without hardening and } \\
\text { traces of overshoot, with the inside of the } \\
\text { product. }\end{array}$ \\
\hline
\end{tabular}

\section{Results and discussion}

The organoleptic and physico-chemical properties of various recipes with the addition of raw and blanched pumpkins have been developed and investigated.

Quality of control of cupcakes begins with an organoleptic evaluation: assessing the conformity of the form, surface condition, color, appearance to breakage, taste and smell. The surface of cupcakes should be non-flammable, and manufactured on chemical rashes may have cracks and gaps that do not alter the product's appearance. The color is from light to dark brown[7,8].

Cupcakes should be well baked, without hardening and traces of non-mushrooming; additives are evenly distributed in the products $[9,11]$. 
Table 7

Organoleptic evaluation of cupcakes without pumpkin and with the addition of raw pumpkin

\begin{tabular}{|l|c|c|c|c|c|}
\hline Indicator & $\begin{array}{c}\text { Without } \\
\text { pumpkin }\end{array}$ & $\mathbf{8 \%}$ & $\mathbf{1 6 \%}$ & $\mathbf{2 4 \%}$ & $\mathbf{3 2 \%}$ \\
\hline Shape & $\begin{array}{c}\text { The shape is } \\
\text { slightly } \\
\text { disturbed }\end{array}$ & $\begin{array}{c}\text { The shape is } \\
\text { slightly } \\
\text { disturbed }\end{array}$ & $\begin{array}{c}\text { The shape is } \\
\text { broken, the } \\
\text { dough is } \\
\text { licked when } \\
\text { cooking }\end{array}$ & $\begin{array}{c}\text { The shape is } \\
\text { broken, the } \\
\text { dough is licked } \\
\text { when cooking }\end{array}$ & $\begin{array}{c}\text { The shape is } \\
\text { broken, the } \\
\text { dough is } \\
\text { licked when } \\
\text { cooking }\end{array}$ \\
\hline Scores & 4 & 4 & 3 & 3 & 3 \\
\hline Surface & $\begin{array}{c}\text { Not burnt, } \\
\text { without } \\
\text { cracks and } \\
\text { breaks }\end{array}$ & $\begin{array}{c}\text { Not burnt, } \\
\text { without } \\
\text { cracks and } \\
\text { breaks }\end{array}$ & $\begin{array}{c}\text { Not burnt, } \\
\text { without } \\
\text { cracks and } \\
\text { breaks }\end{array}$ & $\begin{array}{c}\text { The surface is } \\
\text { slightly } \\
\text { uneven }\end{array}$ & $\begin{array}{c}\text { The surface } \\
\text { is slightly } \\
\text { uneven }\end{array}$ \\
\hline Scores & 5 & 5 & 5 & 4 & 4 \\
\hline Color & $\begin{array}{c}\text { Light brown } \\
\text { Brown }\end{array}$ & $\begin{array}{c}\text { Light brown } \\
\text { Scorched, dark } \\
\text { brown }\end{array}$ & $\begin{array}{c}\text { Really } \\
\text { bright, hardly } \\
\text { yellow }\end{array}$ \\
\hline Scores & 4 & 5 & 4 & 3 & 3 \\
\hline $\begin{array}{l}\text { View in } \\
\text { fault }\end{array}$ & $\begin{array}{c}\text { Well baked } \\
\text { cupcake }\end{array}$ & $\begin{array}{c}\text { Well baked } \\
\text { cupcake }\end{array}$ & $\begin{array}{c}\text { Well baked } \\
\text { cupcake }\end{array}$ & $\begin{array}{c}\text { Not all parts } \\
\text { are baked }\end{array}$ & $\begin{array}{c}\text { Not all parts } \\
\text { are baked }\end{array}$ \\
\hline Scores & 5 & 5 & 5 & 4 & 4 \\
\hline
\end{tabular}

Table 8

Organoleptic evaluation of cupcakes without pumpkin and with the addition of blanched pumpkin

\begin{tabular}{|l|c|c|c|c|c|}
\hline Indicator & $\begin{array}{c}\text { Without } \\
\text { pumpkin }\end{array}$ & $\mathbf{8 \%}$ & $\mathbf{1 6 \%}$ & $\mathbf{2 4 \%}$ & $\mathbf{3 2 \%}$ \\
\hline Shape & Correct shape & Correct shape & $\begin{array}{c}\text { Correct } \\
\text { shape }\end{array}$ & Correct shape & $\begin{array}{c}\text { Correct } \\
\text { shape }\end{array}$ \\
\hline Scores & 5 & 5 & 5 & 5 & 5 \\
\hline Surface & $\begin{array}{c}\text { Not burnt, } \\
\text { without } \\
\text { cracks and } \\
\text { breaks }\end{array}$ & $\begin{array}{c}\text { Not burnt, with } \\
\text { characteristic } \\
\text { cracks }\end{array}$ & $\begin{array}{c}\text { Not burnt, } \\
\text { without } \\
\text { cracks and } \\
\text { breaks }\end{array}$ & $\begin{array}{c}\text { Not burnt, } \\
\text { without } \\
\text { cracks and } \\
\text { breaks }\end{array}$ & $\begin{array}{c}\text { The } \\
\text { surface is } \\
\text { slightly } \\
\text { uneven }\end{array}$ \\
\hline Scores & 5 & 5 & 5 & 4,5 & 4 \\
\hline Color & $\begin{array}{c}\text { Light brown } \\
\text { Light brown }\end{array}$ & $\begin{array}{c}\text { Light brown } \\
\text { Scorched, } \\
\text { dark brown }\end{array}$ & $\begin{array}{c}\text { Really } \\
\text { bright, } \\
\text { hardly } \\
\text { yellow }\end{array}$ \\
\hline Scores & 4 & 4 & 4 & 3 & 3 \\
\hline $\begin{array}{l}\text { View in } \\
\text { fault }\end{array}$ & Well baked & Well baked & Well baked \\
cupcake & cupcake & $\begin{array}{c}\text { Not all parts } \\
\text { are baked }\end{array}$ & $\begin{array}{c}\text { Not all } \\
\text { parts are } \\
\text { baked }\end{array}$ \\
\hline Scores & 5 & 5 & 5 & 4 & 4 \\
\hline
\end{tabular}



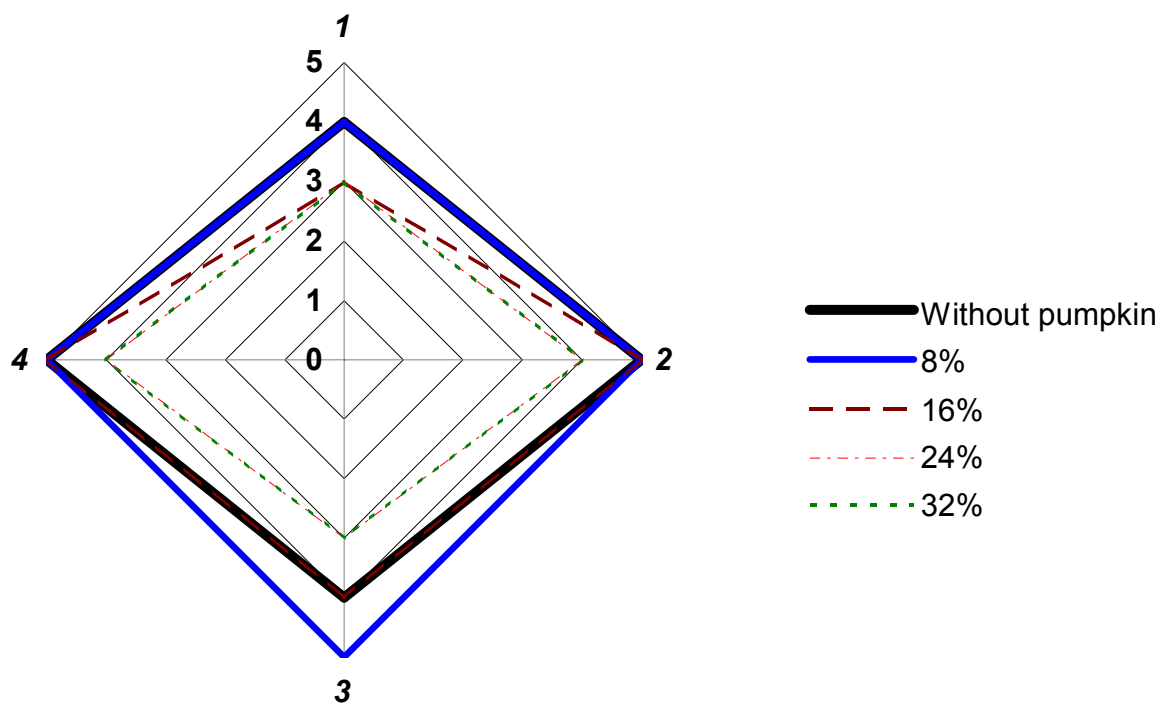

$24 \%$
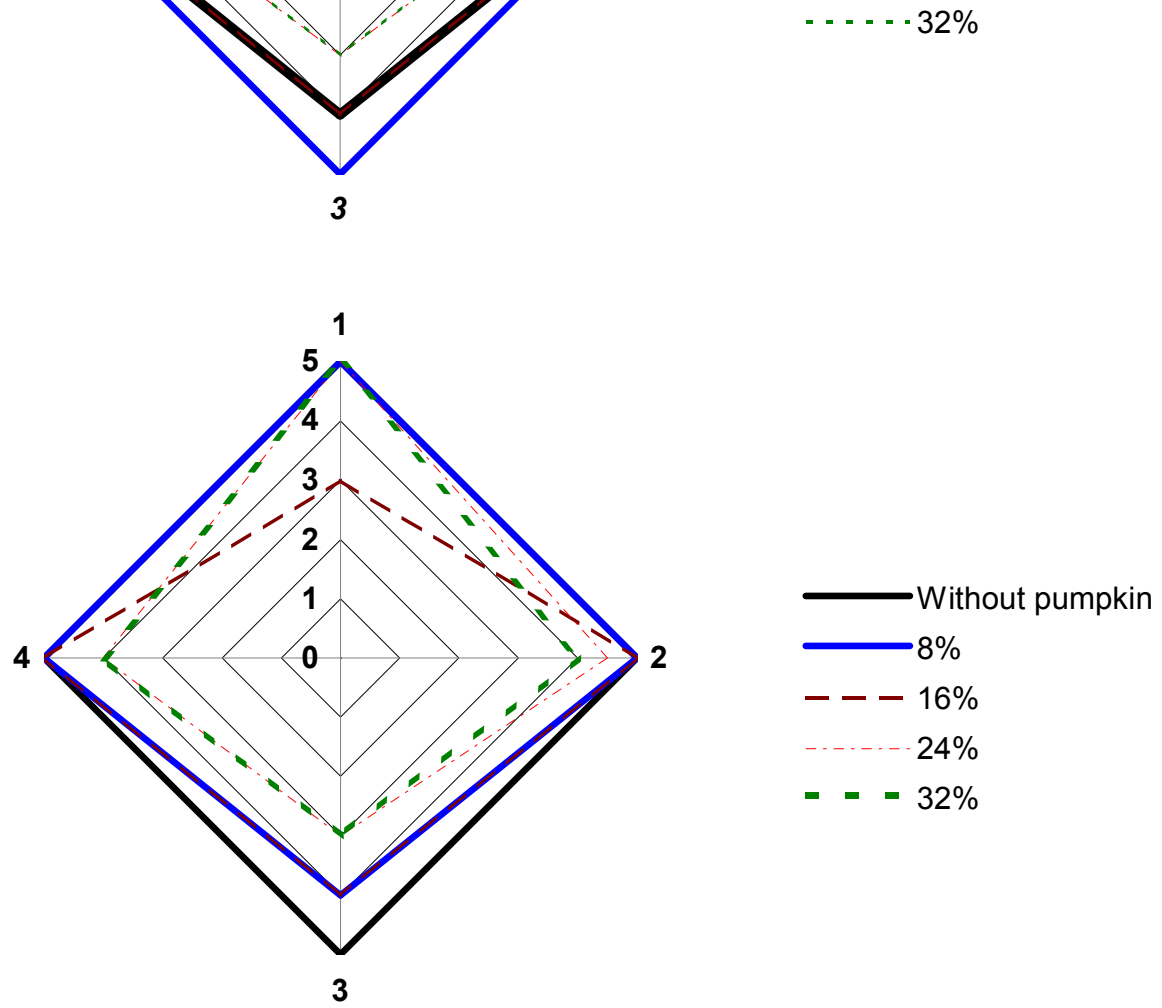

Figure 2. Profileratives of the organoleptic quality assessment of cakes with the addition of raw pumpkin and blanched pumpkin respectively

The results of rheological researches of the physical and chemical properties of various recipes with the addition of raw and blanched pumpkins are given below. 

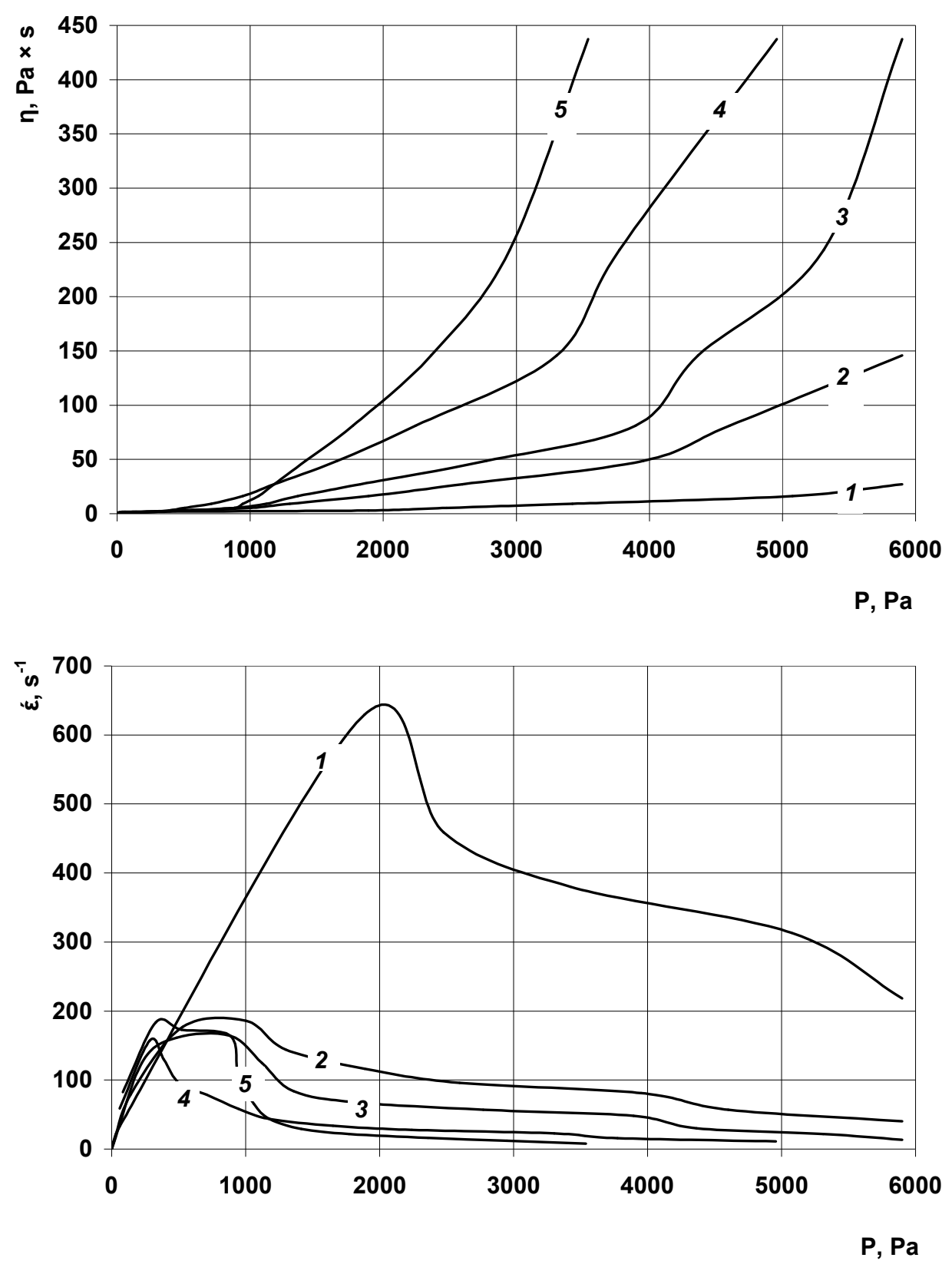

Figure 3. Rheological curves of viscosity and flowing of dough with the addition of raw pumpkin:

1 - classical recipe;

2 - recipe with adding $8 \%$ of pumpkin;

3 - recipe with adding $16 \%$ of pumpkin;

4 - recipe with adding $24 \%$ of pumpkin;

5 - recipe with adding $32 \%$ of pumpkin. 

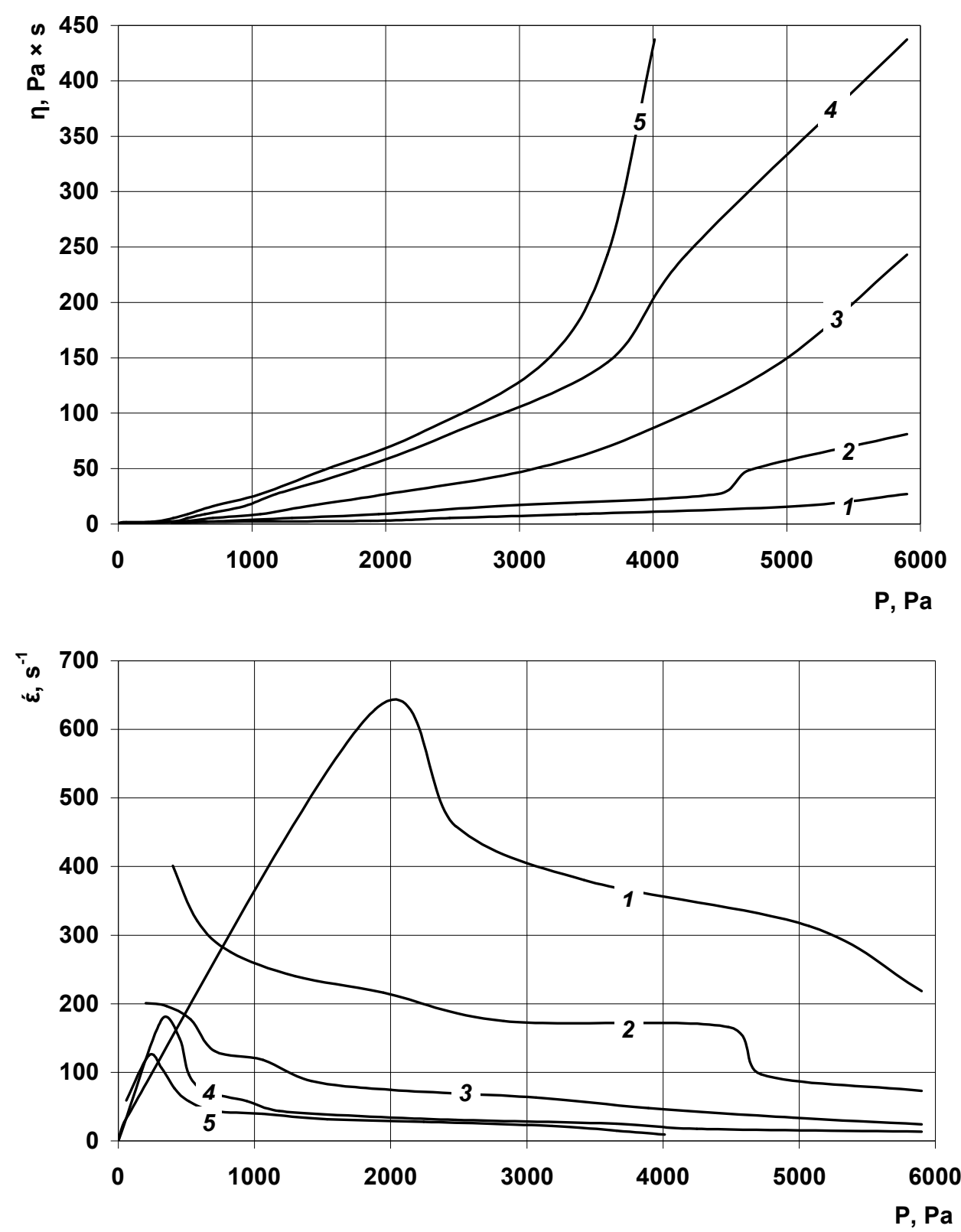

Figure 4. Rheological curves of viscosity and flowing of dough with the addition of blanched pumpkin

1 - classical recipe;

2 - recipe with adding $8 \%$ of pumpkin;

3 - recipe with adding $16 \%$ of pumpkin;

4 - recipe with adding $24 \%$ of pumpkin;

5 - recipe with adding $32 \%$ of pumpkin. 


\section{— Food Technologies}

By viscosity, the most similar to the classical receipe is a sample containing $24 \%$ blanched pumpkin.

With the help of conducted organoleptic and physicochemical studies, we can conclude that the formulation with the addition of $24 \%$ blanched pumpkin is the most successful.

Creation of a new type of cupcake will promote the expansion of the range of flour confectionery products of functional action. Has been proven that adding the pumpkin to cupcake leads to the enrichment of the product with biologically valuable components, vitamin and mineral complexes and compounds of antioxidants contained in this raw material [9].

\section{Conclusions}

The use of pumpkin in the manufacture of cupcakes is appropriate in view of the enrichment of the product with biologically valuable components, vitamin-mineral complexes and compounds of antioxidants contained in this raw material. Creation of a new type of cupcake will contribute to the expansion of the range of flour confectionery products of functional action.

\section{References}

1. Pogarskaya V.V., Pavlyuk R.Y. et al. (2013), Activation of hydrophilic properties of plant carotene carotinoids: monograph, Finart, Kharkiv.

2. Goni I., Serrano J., Saura-Calixto F. (2006), Bioaccessibility of $\beta$-Carotene, Lutein, and Lycopene from Fruits and Vegetables, Journal of Agricultural and Food Chemistry, 54(15), pp. 5382-5387.

3. Mazaraki A.A., Kravchenko M.F. (2012) Technology of functional products: monograph, Kyiv national economical university, Kyiv.

4. Rakcejeva R. Galoburda, Cude L., Strautniece E. (2011), Use of dried pumpkins in wheat bread production, Procedia Food Science, 1, pp. 441-447.

5. Xanthopoulou M.N., Nomikos T. (2009), Antioxidant and lipoxygenase inhibitory activities of pumpkin seed extracts, Journal of Food Research International, 42(5-6), pp. 641-646.

6. Alibas I. (2007), Microwave, air and combined microwave-air-drying parameters of pumpkin slices, Food Science and Technology, 40(8), pp. 1445-1451.

7. Primo-Martín C., Beukelaer H., Hamer R.J.(2008), Fracture behaviour of bread crust: Effect of ingredient modification, Journal of Cereal Science, 48(3), pp. 604-612.

8. Kaplina, T. V., Firsova R. M., Kaplina T.V., Dorokhina M.O. (2006), The biostability of wheat flour to a large extent depends on the physical methods of cultivation, Baking and confectionery industry, 1(1), pp. 20-21.

9. Podrushniak A. (2004) Safe food, low-quality products, Food and processing industry, 11, pp. 8 9.

10. Dzungja O.V. (2009), Prospects for the use of persimmons in the production of food products of functional purpose, Goods and Markets, 2, pp. 60-65.

11. Pavlyuk R.Y., Pogarskaya V. V., Pavlyuk R. Y., Bilenko L.M., Yurieva A.O., Gasanova A.E., Maximova N.P. (2017), Development of new types of buns for sandwiches for health nutrition vitaminized with carotenoid plant nano additives, Scientific journal «Sciencerise», 5(34), pp. $57-$ 64.

12. Pabon P., Ternström S., Lamarche A., (2011), Fourier Descriptor Analysis and Unification of Voice Range Profile Contours: Method and Applications, Journal of Speech, Language, and Hearing Research, 54, pp. 755-776. 